\title{
RUNTUHNYA BENTENG KOTA MAS SILANG LITERASI SEJARAH
}

\author{
The Collapse of Fort Kota Mas: The Historical Cross of Literation
}

\section{Irna Saptaningrum ${ }^{1}$, Agus Tri Hascaryo ${ }^{2}$, Hasanuddin Anwar ${ }^{3}$, Romi Hidayat ${ }^{4}$, Buhanis Ramina ${ }^{4}$, Vivi Sandra Sari ${ }^{1}$}

\author{
${ }^{1}$ Balai Arkeologi Sulawesi Utara, ${ }^{2}$ Universitas Islam Indonesia Yogyakarta, ${ }^{3}$ Balai \\ Pelestarian Nilai Budaya Sulawesi Utara, ${ }^{4}$ Balai Pelestarian Cagar Budaya Gorontalo \\ ${ }^{1}$ Jalan Pingkan Matindas Nomor 92, Manado 95128 \\ E-mail: ${ }^{1}$ terakota_ir08@yahoo.co.id
}

\begin{abstract}
Fort Kota Mas is a Spanish fort in the form of a building complex that is no longer intact. The remaining parts of the fort include part of the wall, bastion, and gate. This fort is located in Kwandang Village, North Gorontalo Regency, and Gorontalo Province. It is geographically located at coordinates $0^{\circ} 50^{\prime} 10.85$ "N and 122 54' 47.57" E. The construction of the fort wall and the bastion has a thickness of $0.8-1.2 \mathrm{~m}$, which is composed of various rocks with mortal adhesive or lime space. The location of Fort Kota Mas in the Kwandang Bay area is a strategic location for the trade route of agricultural products and gold ore in the 15th to 19th centuries. Therefore, the Portuguese and the Dutch seized this area from the Spanish. The bay's location is also in earthquake fault line trending Southeast - Northwest, which can cause earthquake and tsunami disasters. The earthquake and tsunami that significantly affected the integrity of the fort occurred in 1856 (Gorontalo), 1858 (Minahasa), and 1859 (Ternate and Minahasa). Based on the historical records, it is not yet known the cause of the collapse of Fort Kota Mas, either the chronology or the cause.
\end{abstract}

Keywords: Fort, Kota Mas, tsunami, gold

\begin{abstract}
Abstrak
Benteng Kota Mas adalah benteng Spanyol yang berupa sisa-sisa bangunan dinding, bagian bangunan bastion, dan bagian dari gerbang yang terletak di Desa Kwandang, Kabupaten Gorontalo Utara, Propinsi Gorontalo, secara geografis berada pada koordinat 000 50' $10,85^{\prime}$ " Lintang Utara dan 1220 54' 47,57' Bujur Timur. Benteng ini berupa kompleks bangunan yang sudah tidak utuh, hanya beberapa bagian bangunan tampak berdiri di atas lahan morfologi dataran lembah. Konstruksi tembok benteng beserta bastion memiliki ketebalan 0,8 - 1,2 m yang tersusun atas aneka batuan dengan perekat mortal atau spasi kapur. Reruntuhan bangunan dirikan di atas endapan aluvial lanau pasiran. Lokasi Benteng Kota Mas berada pada kawasan Teluk Kwandang merupakan lokalitas yang strategis dalam jalur perdagangan rempah-rempah dan bijih emas pada abad ke-15 hingga ke-19. Oleh karena itu, Portugis dan Belanda merebut kawasan ini dari kaum Spanyol. Teluk ini terletak juga pada lengan atas Sulawesi yang merupakan jalur patahan besar berarah Tenggara - Barat laut melewati wilayah Gorontalo Utara, hal ini dapat menjadi bencana kegempaan dan tsunami. Bencana kegempaan dan tsunami yang signifikan berpengaruh terhadap keutuhan bangunan benteng, terjadi pada tahun 1856 (Gorontalo), 1858 (Minahasa), dan 1859 (Ternate dan Minahasa). Dalam catatan sejarah, belum absolut diketahui runtuhnya Benteng Kota Mas, baik kronologi maupun penyebabnya.
\end{abstract}

Kata kunci: Benteng, Kota Mas, tsunami, gold 


\section{PENDAHULUAN}

Benteng Kota Mas secara administratif berada di wilayah Dusun Moluo, Desa Cisadane, Kecamatan Kwandang, Kabupaten Gorontalo Utara. Letak Benteng Kota Mas tidak jauh dari garis pantai dengan jarak sekitar dua kilometer ke arah Barat. Lokasi ini berupa dataran rendah pantai yang di sekitarnya merupakan daerah pemukiman penduduk. Benteng Kota Mas atau disebut juga dengan nama Ota Maas. Kata "ota" merupakan istilah lokal yang berarti benteng. Secara geografis berada pada koordinat $0^{\circ}$ 50' 10,85" Lintang Utara dan $122^{\circ}$ 54' 47,57' Bujur Timur. Benteng ini berupa kompleks bangunan yang sudah tidak utuh, menyisakan satu bastion di sudut timur laut dan pintu gerbang di sisi barat serta reruntuhan dinding benteng di beberapa bagian. Ditemukan pula satu bekas sumur berdekatan dengan runtuhan struktur bangunan di area tengah kompleks benteng. Benteng ini berdiri di atas lahan morfologi dataran lembah. Lembah tersebut berbatasan dengan perbukitan batuan vulkanik di bagian timur, selatan, dan barat, sedangkan bagian utara adalah dataran pantai. Selain itu terdapat pula Sungai Kwandang di sisi timur yang mengalir sepanjang waktu, walaupun mengalami perubahan volume saat musim hujan dan kemarau.

Dalam lintasan sejarah, terdapat tulisan Riedel (1869) yang menyinggung tentang pendirian benteng di Kwandang yang termaktub dalam sebuah kontrak yang ditandatangani pada tanggal 22 Juli 1765 antara penguasa Limuto, dengan Gubernur dan Direktur Maluku. Isi perjanjian menyinggung tentang penyetoran emas, melarang pelayaran orang asing di sungai-sungai dan pelabuhan, serta membangun dua benteng di Kwandang atau Wanengo (Riedel, 1869). Dua benteng yang ada di Kwandang adalah Benteng Kota Mas dan Benteng Oranje. Berdasarkan tulisan tersebut, bahwa satu benteng yang dikatakan tinggal puing adalah Benteng Kota Mas, sedangkan Benteng Leiden adalah nama lain dari Benteng Oranje.

Rujukan lain tentang Benteng Kota Mas terdapat dalam majalah Oudheidkundig Verslag 1928, digambarkan kondisi Benteng Kota Mas yang disebut dengan nama Kota Mas. Kondisi benteng sudah runtuh, namun masih memiliki bagian-bagian ruangan. Dua bastion dari empat bastion yang ada masih terlihat. Reruntuhan fondasi bangunan di bekas benteng, pecahan dinding, sumur, dan gerbang, tertutup oleh vegetasi yang lebat (Gambar 1). Lebih lanjut dikatakan jika ada saksi mata yang mengatakan bahwa pada tahun 1911 benteng tersebut masih memiliki banyak sekali tempat tinggal dengan kondisi masih lumayan utuh, namun penduduk sekitar telah mengambil dan menggunakan batu reruntuhan benteng tersebut untuk membangun sebuah masjid (Wall, 1929). 


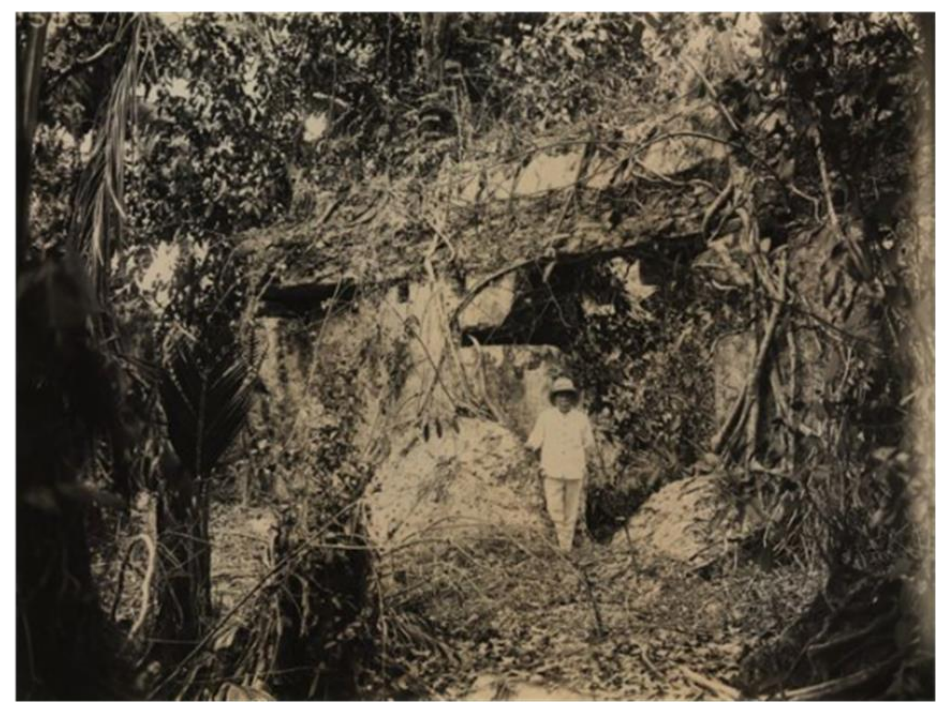

Gambar 1. Gambaran Benteng Kota Mas pada tahun 1928 (Sumber: Wall, 1929).

Penelitian awal dilakukan pada tahun 1997 dengan kegiatan survei kondisi Benteng Kota Mas serta membuka satu kotak ekskavasi. Hasil penelitian ini berupa denah Benteng Kota Mas berbentuk empat persegi panjang dengan perkiraan luas 160 meter x 103 meter yang memanjang dari Utara ke Selatan. Penelitian berikut dilakukan pada tahun 2001 menyingkap struktur pondasi yang diduga bastion lengkung di bagian utara dan barat. Pada sisi barat tersingkap keberadaa dinding benteng, namun belum dapat dipastikan bentuknya. Kotak ekskavasi di bagian timur menyingkap struktur pondasi yang diduga struktur dinding benteng (Budiharto, 2001). Pada tahun 2002 dibuka 2 (dua) kotak gali di sisi utara. Hasil penelitian itu berupa pondasi dinding berbentuk lurus mengarah utara - selatan (Fahriani, 2002). Pada tahun 2010, Pusat Dokumentasi Arsitektur juga menginventarisir Benteng Kota Mas. Identifikasi terhadap bangunannya disebutkan jika benteng ini dibangun oleh orang Spanyol yang lebih dikenal dengan nama Kota Mas, ukurannya lumayan besar dengan empat bastion (Pusat Dokumentasi Arsitektur, 2010).

Balai Pelestarian Cagar Budaya Gorontalo melakukan ekskavasi parit uji untuk penyelamatan Benteng Kota Mas tahun 2018 di sisi barat. Hasil ekskavasi yaitu menemukan fakta bahwa struktur batu menunjukkan orientasi yang belum dapat dibaca jelas. Struktur dinding benteng rubuh berdekatan dengan struktur pondasinya, padahal runtuhan tersebut tidak semua hancur, di beberapa bagian masih berbentuk struktur tembok batu (Hidayat et al., 2018).

Balai Arkeologi Sulawesi Utara dan Balai Pelestarian Cagar Budaya Gorontalo melakukan kegiatan ekskavasi lanjutan pada tahun 2019 di waktu yang berbeda. Balai Arkeologi menitikberatkan pada pencarian struktur bastion di tiga sudut kompleks benteng dan juga di bagian dinding tembok pintu gerbang. Secara keseluruhan telah dibuka 13 kotak di sudut barat daya, 4 kotak di sudut tenggara, 2 kotak di sudut barat laut dan 2 kotak tambahan di dekat tembok pintu gerbang. Area di barat daya jejak 
struktur bastion belum mendapat data yang signifikan. Sedang di area tenggara telah tampak adanya struktur bastion, meskipun bentuknya belum jelas. Pada posisi ekskavasi di sudut barat laut, dua kotak dibuka dengan meneruskan kotak yang telah dibuka sebelumnya. Hasilnya telah didapatkan sambungan struktur batu sebagaimana dimaksud, namun orientasinya belum jelas benar. Sedang titik ekskavasi di bagian dinding pagar pintu gerbang mendapatkan hasil jika fondasi benteng dibuat dengan kedalaman berkisar $70 \mathrm{~cm}$. Untuk ukuran bangunan yang demikian tebal dan tinggi, fondasi ini terlihat dangkal (Saptaningrum et al., 2019).

BPCB kembali melanjutkan ekskavasi penyelamatan Benteng Kota Mas dengan membuka kotak lanjutan dimulai dari keberadaan struktur dinding tembok benteng sisi utara. Posisi struktur tersebut miring $45^{\circ}$ ke utara. Setelah berhasil membuka 23 kotak ekskavasi terlihat jika struktur tersebut merupakan bagian dari struktur dinding benteng yang membentang di sisi utara menyambung hingga ke arah sudut barat laut kompleks benteng. Struktur dasar fondasi benteng disusun dengan material batu andesit dengan ketebalan $90 \mathrm{~cm}$. Pada area sudut barat laut yang merupakan titik konsentrasi struktur batuan yang diduga bastion, mulai dikupas. Penampakan struktur batu di area tersebut tidak mengindikasikan adanya bentuk struktur bastion segi delapan (Hidayat et al., 2018).

Selain itu kotak gali juga dibuka di bagian sisi tenggara, melanjutkan ekskavasi yang telah dibuat oleh Balai Arkeologi Sulawesi Utara sebelumnya. Hasil dari bukaan kotak tersebut menunjukkan jika struktur yang diduga bastion tersebut, ternyata struktur batu yang roboh (Saptaningrum et al., 2019). Dengan demikian, bentuk struktur bastion di sudut tenggara belum dapat dipastikan.

Berdasarkan pengamatan dalam penelitian arkeologi yang telah dilakukan sebanyak enam tahapan (tahun 1997, 2001, 2002, 2010, 2018, dan 2019) diketahui bahwa lokalitas benteng pada masa lampau berdekatan dengan garis pantai yang berdinamika kebencanaan cukup tinggi berupa gempa tektonik, tsunami, dan adanya perebutan penguasaan wilayah Kwandang oleh VOC. Selain itu pula, tersingkapnya sistem struktur bangunan benteng dalam kondisi runtuh. Hasil tersebut memberikan hipotesis permasalahan besar yang akan diungkap dalam pembahasan, yaitu faktorfaktor penyebab runtuhnya benteng Kota Mas, apakah disebabkan oleh kondisi alam dan atau serangan oleh musuh untuk menguasai jalur pelayaran dan perdagangan.

Tujuan penelitian ini untuk mengetahui runtuhnya Benteng Kota Mas. Metode yang dilakukan adalah kajian pustaka dengan melihat beberapa sumber tertulis berupa arsip, dokumen lama, serta sumber piktorial seperti peta dan foto-foto yang terkait dengan Benteng Kota Mas. Hasil penelusuran pustaka kemudian dikaitkan dengan fenomena kebencanaan mengingat lokasi benteng yang berada di Sesar Gorontalo atau zona Subduksi Sulawesi Utara. 


\section{PEMBAHASAN}

\section{Lokalitas dan Tapak Benteng Kota Mas}

Studi literasi Benteng Kota Mas dilakukan untuk mengetahui kronologi dan kondisi sosial politik yang menyelimuti selama ini. Data-data tertulis belum banyak yang terbaca dan membuktikan adanya hitam di atas putih tentang eksistensi akupasi, politik, sosial, ekonomi benteng ini. Sementara itu, mengutip informasi dari J.F.G. Riedel (1869) bahwa pendirian benteng di Kwandang termaktub dalam sebuah kontrak yang ditandatangani pada 22 Juli 1765 antara penguasa Limuto dengan Gubernur dan Direktur Maluku (Riedel, 1869).

Encyclopaedie van Nederlands-Indie dan artikel berjudul "Oudheidkundig Opsporingen" yang terbit dalam De Indische Courant tanggal 18 Desember 1928 mengatakan bahwa benteng ini (kemungkinan) merupakan benteng milik Spanyol yang memiliki hubungan dengan aktivitas pertambangan emas di daerah Gorontalo Utara pada masa lalu (Anonim, 1928b). Namun demikian, sebuah artikel berjudul "De Nederlandsch Oudheden in Celebes" yang terbit di dalam Bataviaasch Nieuwsblad pada tanggal 27 Desember 1928 menuliskan hal berbeda. Artikel berita yang membahas mengenai tinggalan arkeologis di Pulau Sulawesi tersebut mengatakan bahwa Benteng Kota Mas diduga merupakan stad (dalam Bahasa Belanda bisa diartikan sebagai kota/wilayah/sektor) pertambangan emas Portugis (Anonim, 1928a). Sejauh ini, informasi yang lebih lengkap mengenai Benteng Kota Mas dapat ditemukan dari laporan kunjungan dinas C.B.H Von Rosenberg ke Gorontalo pada tahun 1863 dan di dalam "Oudheidkundig Verslag 1928". Dari kedua arsip tersebut beberapa informasi terkait Benteng Kota Mas berhasil diketahui dan dirangkum sebagai berikut ini.

Benteng Kota Mas terletak di sebelah barat sebuah jalan utama, di seberang rumah controleur di Kwandang dan hanya sepuluh menit berjalan kaki dari rumah Marsaoleh pada masa itu. Benteng ini diceritakan memiliki luas 250 hasta persegi ( $\pm 1,12$ hektar) dengan dinding yang terbuat dari batu karang setebal 1 depa dan tinggi 4 hasta yang mengelilingi bagian dalamnya (Rosenberg, 1865).

"Oudheidkundig Verslag 1928" menuliskan bahwa pada awal abad ke-20, Benteng Kota Mas telah dalam kondisi rusak. Meskipun demikian, bekas fondasi bangunan, pecahan dinding, sumur dan gerbang masih bisa dilihat. Terbitan berkala tersebut bahkan menginformasikan bahwa pada tahun 1911, arsitektur Benteng Kota Mas sebenarnya masih cukup bisa diidentifikasikan dengan baik (Wall, 1929). Selain itu, Rosenberg juga menambahkan bahwa benteng ini dibangun dengan dua gerbang sebagai akses keluar-masuk, dimana yang lebih besar terletak di sebelah barat dan yang lebih kecil terletak di timur. Terdapat sebuah sungai kecil yang mengalir melalui Benteng Kota Mas dimana aliran airnya diarahkan keluar ke laut dengan sistem kanal (Rosenberg, 1865). Kemungkinan besar, benteng ini dulunya memang terletak lebih dekat dengan bibir pantai jika dibandingkan dengan kondisi sekarang. 


\section{Penyebab keruntuhan}

Puing-puing reruntuhan bangunan tidak menjadi perhatian masyarakat menyebabkan kompleks benteng tidak terurus (Wall, 1929). Kondisi demikian berlangsung hingga akhir abad 19, nampaknya bukanlah hal yang aneh jika laporan yang ditulis Rosenberg memang benar adanya. Salah satu informasi di dalam laporan perjalanan dinas tersebut mengatakan bahwa Benteng Kota Mas telah menjadi reruntuhan selama lebih dari lima puluh tahun (Rosenberg, 1865). Hal ini juga bisa diartikan bahwa benteng tersebut telah tidak difungsikan selama lebih dari setengah abad lamanya. Jika ditarik dari tahun dimana laporan Rosenberg diterbitkan, yakni 1865, atas dasar perjalanannya tahun 1863 maka dapat dikatakan bahwa benteng ini kemungkinan telah tidak digunakan sejak tahun 1813 atau lebih (awal abad ke-19).

\section{Peperangan}

Bagaimana dengan penguasaan VOC terhadap pusat-pusat perdagangan emas dan rempah-rempah termasuk Kwandang. VOC masuk ke Gorontalo dan Kwandang sejak tahun setelah perjanjian Bungaya 1667, bahwa VOC menguasai dari Mandar sampai Manado, melewati Kwandang dari Manado-Amurang-Bintauna-Kwandang-Limboto. Asumsinya adalah bahwa VOC selalu ingin ekspansi pusat-pusat niaga dengan cara penyerangan, termasuk pula di Benteng Kota Maas yang dapat menyebabkan kerusakan bangunan benteng (Laupe, 1867).

Penyerangan terhadap Benteng Kota Mas pernah dilakukan saat terjadinya konflik antara VOC dan orang-orang Bugis terkait tentang kebijakan VOC yang membatasi pedagang Bugis di Pelabuhan Kwandang. Pada tahun 1790, orang-orang Bugis dipimpin Puang Nyili dibantu dengan orang-orang Ilanun menyerang perwakilan VOC. Hal ini dilatarbelakangi oleh pembunuhan putra Pua Nyili bernama Labajo oleh pasukan wakil VOC. Labajo berkunjung ke Kwandang tanpa izin dari VOC, ia bersama pengikutnya menentang dan melawan VOC dan akhirnya dibunuh (Riedel, 1869). Selama tiga bulan pasukan Bugis menguasai Kwandang namun terdesak setelah datang armada dari Ternate yang terdiri dari 30 korra-korra (Rosenberg, 1865). Meski konflik yang berlangsung lama, peperangan ini tidak berpengaruh banyak pada kerusakan benteng.

\section{Zona bencana geologi}

Posisi benteng cukup jauh dari garis pantai saat ini, namun ada kemungkinan pada masa tertentu terjadi perubahan garis pantai yang mengalami transgresi yaitu air laut menuju ke darat mendekati kawasan Benteng Kota Mas. Kondisi demikian terjadi pada abad 14 - 16, berdasarkan data perubahan muka air global naik hingga 8 meter dari muka air laut saat ini (Hascaryo, 2019).

Perhatian terhadap puing-puing benteng mulai menjadi intensif, sejak dilakukannya penelitian arkeologi mengenai Benteng Kota Mas yang berada di Kecamatan Kwandang. Penelitian dilakukan oleh Balai Arkeologi Sulawesi utara dan Balai Pelestarian Cagar Budaya Gorontalo sejak tahun 1997 hingga tahun 2019. Metode 
dan teknik yang digunakan baik dengan survei maupun ekskavasi di kompleks bangunan benteng dan sekitarnya untuk mengungkap desain besarnya yaitu kronologi, strukturalisme bangunan, pola akupasi, dan studi akademis pelestarian.

Hasil ekskavasi dan penelitian yang telah didapat menyingkap konstruksi Benteng Kota Mas berupa sisa-sisa bangunan dinding atau tembok, yang membentuk struktur arsitektur kompleks ruang. Sisa-sisa jejak bangunan yang tampak dipermukaan terdiri dari beberapa bagian dinding (tembok) keliling, bagian bangunan bastion, dan bagian dari gerbang. Bagian-bagian bagunan tersebut dibangun menggunakan bahan terumbu karang lebih dominan selain andesit, breksi tufaan, batuan metasedimen, dan basal. Bahan-bahan tersebut berukuran bongkah (diameter 10-20 cm) yang berbentuk agak membulat-agak menyudut. Bahan-bahan tersebut dipasang bersusun yang dihubungkan dengan perekat mortel atau spesi. Spesi sebagai pengikat antar bahan menggunakan material gamping keprus, yaitu batugamping dan terumbu karang yang dihaluskan dengan campuran pasir halus. Mortel atau spesi digunakan juga untuk lapisan terluar (plester) bangunan dinding (Saptaningrum et al., 2019).

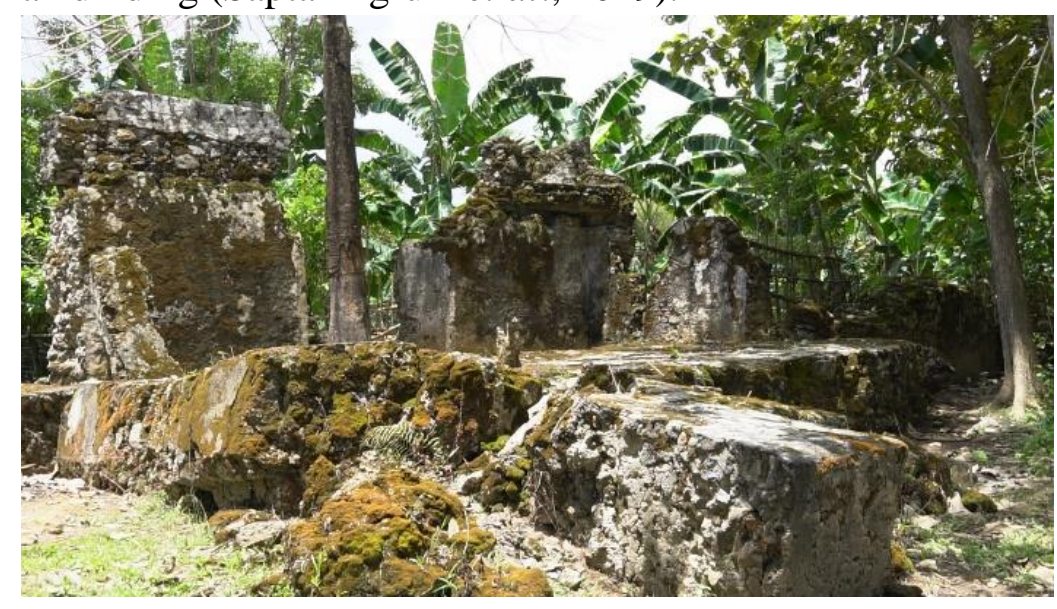

Gambar 2. Dinding bangunan benteng yang roboh (Sumber: Balai Arkeologi Sulawesi Utara, 2019).

Pada beberapa spesi dinding, tersingkap fragmen terumbu dan arang berukuran panjang $1-3 \mathrm{~cm}$, kemungkinan arang bukan sebagai pencampur spesi tetapi tidak sengaja keberadaannya. Spesi kapur pada bangunan benteng ini dapat diidentifikasikan mempunyai sifat plastis yang baik (tidak getas), member kekuatan pada tembok, dapat mengeras dengan cepat dan mudah, mudah dikerjakan, dan mempunyai ikatan yang bagus dengan batu. Konstruksi bangunan dinding atau tembok benteng beserta bastion memiliki ketebalan 0,8 - 1,2 m yang disusun dari aneka bahan dengan perekat mortel atau spasi kapur menjadi pertimbangan utama untuk kekuatan bangunan yang dirikan di atas satuan batuan aluvial lanau pasiran. Bukti data hasil ekskavasi memperlihtkan bahwa bangunan benteng tidak menggunakan bangunan pondasi. Bangunan dinding atau tembok benteng maupun bastion bagian bawah, langsung berdiri di atas batuan dasar, artinya tidak melakukan pembuatan galian untuk menanam bagian bawah bangunan tersebut (Gambar 3). Bagian dasar bangunan, diletakkan bongkahan terumbu 
karang yang kemungkinan untuk perkuatan. Berdasarkan litologi batuan dasar di lembah dataran aluvial daerah Kwandang dan sekitarnya berupa lanau pasiran yang memiliki tahanan geser cukup baik untuk meredam getaran jika terjadi goncangan seperti gempa bumi.

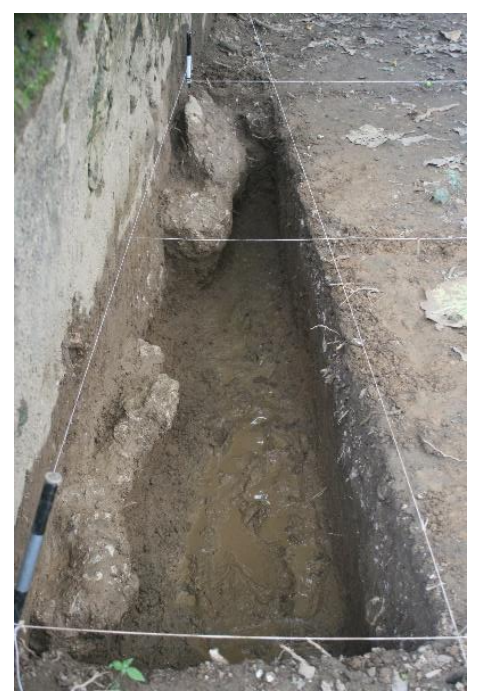

Gambar 3. Perkuatan bangunan benteng menggunakan pondasi yang langsung diletakkan di atas permukaan paleosoil (Sumber: Balai Arkeologi Sulawesi Utara, 2019).

Gempa bumi tektonik di wilayah Gorontalo Utara dan sekitarnya disebabkan oleh pergerakan aktif struktur patahan lempeng lengan atas Sulawesi besar berarah Tenggara-Barat laut melalui wilayah tersebut, hal ini dapat menjadi bencana kegempaan (Gambar 4). Bencana tersebut berpengaruh juga terhadap keutuhan bangunan pemukiman dan benteng. Salah satu contoh kerobohan yang disebabkan kemungkinan oleh gempa bumi yaitu tersingkapnya bangunan tembok yang masih relative utuh dan memanjang pada sisi timur dan selatan dengan kedudukan miring atau roboh ke arah luar benteng (Saptaningrum et al., 2019).

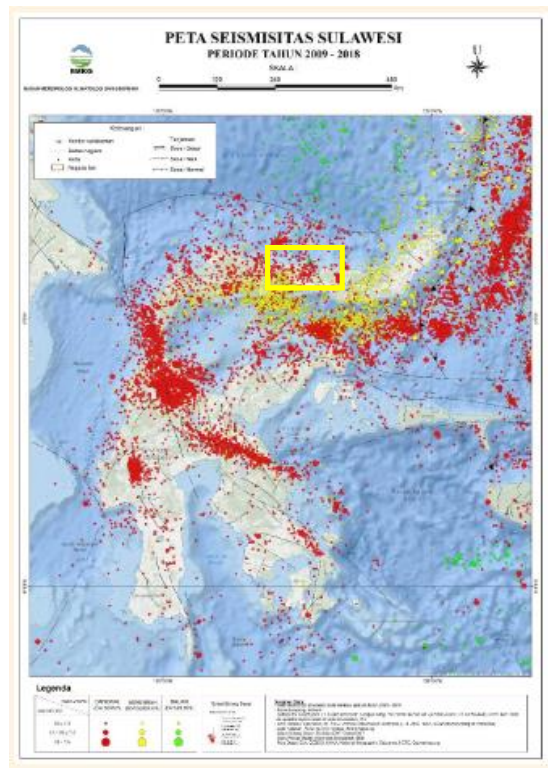


Gambar 4. Peta Seismitas Sulawesi (garis kuning menunjukkan Gorontalo Utara) (Sumber: Pusat Gempabumi dan tsunami BMKG, 2019).

Berdasarkan data publikasi BMKG, daerah Gorontalo Utara termasuk Kwandang berada pada daerah dengan tingkat kegempaan tinggi. Gempa bumi pernah terjadi di Sulawesi Utara pada tahun 1845 yang menyebabkan bangunan rumah dari bata roboh. Selanjutnya pada 1858 terjadi gempa yang mengakibatkan tsunami (Pusat Gempabumi dan Tsunami BMKG, 2019). Harris, R dan Major, J, menyebutkan pernah terjadi gempa dan tsunami besar yang dirasakan di wilayah Gorontalo dan Semenanjung Minahasa serta di wilayah Sulawesi Utara pada tahun 1856. Akibat guncangan gempa yang dashyat tersebut merusak tembok-tembok benteng. Kegempaan dan tsunami yang terjadi disebabkan bergeraknya Sesar Gorontalo atau zona Subduksi Sulawesi Utara. Tiga tahun kemudian, wilayah Gorontalo dan sekitarnya di guncang gempa kembali pada tahun 1859 dengan kekuatan yang besar selama lima menit. Goncangan gempa susulan sering terjadi sejak dini hingga malam hari yang disertakan dengan tsunami hingga rumah dan beberapa bangunan benteng roboh (Harris \& Major, 2016).

\section{SIMPULAN}

Studi literasi catatan dan berita perjalanan menjelaskan terjadinya konflik perebutan kekuasaan wilayah Kwandang sebagai daerah penghasil rempah dan emas antara Spanyol - Masyarakat Bugis - VOC. Konflik yang disebabkan oleh Masyarakat Bugis tidak mempengaruhi keutuhan Benteng Kota Mas. Pada saat VOC menginginkan penguasaan wilayah penghasil rempah dan emas, mereka menggunakan politik perjanjian Saragosa pada tahun 1529 yang menyebabkan Spanyol harus keluar dari wilayah Asia tidak terkecuali Kwandang. Artinya perebutan penguasaan tanpa peperangan, sehingga tidak ada perlakuan perebutan benteng yang menyebabkan kerusakan pada bangunan.

Lokalitas Benteng Kota Mas yang berdekatan dengan garis pantai dan bermorfologi datar akan rentan terhadap kebencanaan tsunami. Selain itu pula kawasan benteng yang terletak pada jalur patahan Gorontalo menambah kerentanan terhadap bencana kegempaan, hal ini menjadi faktor runtuhnya Benteng Kota Mas. Berdasarkan intepretasi literasi sejarah dan kebumian dari abad ke 16-19 wilayah Gorontalo bahwa keruntuhan Benteng Kota Mas lebih disebabkan oleh faktor alam, namun demikian dibutuhkan data-data lapangan dengan melakukan penelitian arkeotsunami yang lebih detil.

\section{DAFTAR PUSTAKA}

Anonim. (1928a). De Nederlandsch Oudheden in Celebes. Bataviaasch Nieuwsblad. https://www.delpher.nl/nl/kranten/view?query=kota+mas+kwandang+\&coll=ddd\& page $=3 \&$ identifier $=$ ddd:011072209:mpeg21:a0009\&resultsidentifier $=$ ddd:0110722 09:mpeg21:a0009 
Anonim. (1928b, December 18). Oudheidkundige Opsporingen. De Indische Courant. https://www.delpher.nl/nl/kranten/view?query=kota+mas+kwandang\&coll=ddd\&i dentifier=ddd:010278757:mpeg21:a0052\&resultsidentifier=ddd:010278757:mpeg2 1:a0052kranten

Budiharto, H. (2001). Kajian Arsitektur Benteng Maas di Kecamatan Kwandang.

Fahriani, I. (2002). Kajian Situs Benteng Maas Kec, Kwandang, Kab. Gorontalo, Provinsi Gorontalo.

Harris, R., \& Major, J. (2016). Waves of destruction in the East Indies: the Wichmenn catalogue of earthquakes and tsunami in the Indonesian region from 1528 to 1877. The Geological Society of London, 441.

Hascaryo, A. T. (2019). Studi Geoarkeologi Bagian Utara Jawa Tengah Untuk Rekonstruksi Lingkungan Hidup, Okupasi, dan Jelajah Manusia Purba Selama Zaman Kuarter. Institut Teknologi Bandung.

Hidayat, R., Saptaningrum, I., Ramina, B., \& Anwar, N. (2018). Ekskavasi Penyelamatan Benteng Maas di Kabupaten Gorontalo Utara.

Laupe, P. A. (1867). Het Journaal Van Padtbrugge's Reis Naar Nord-Celebes En De Noordereeiland. In Bidragen tot de Taal-, Land- en Volkekunde Van NederlandschIndie, deel 2, (BKI) (pp. 150-156).

Pusat Dokumentasi Arsitektur. (2010). Inventory and Identification Forts in Indonesia. Pusat Dokumentasi Arsitektur, Direktorat Peninggalan Purbakala. Kementerian Kebudayaan dan Pariwisata.

Pusat Gempabumi dan Tsunami BMKG. (2019). Katalog gempabumi signifikan dan merusak 1821 - 2018. Badan Metereologi, Klimatologi, dan Geofisika.

Riedel, G. J. F. (1869). Het Landshappen Holontalo, Limoeto, Bone, Boalemo en Katingola of Andagile: Geographische, Statistiche, Historiche en Ethnographische Aanteekeningen. In Tijdschriit Voor Indishe Taal-, Land-en Volkenkunde (TBG), $X I X$.

Rosenberg, C. B. H. von. (1865). Reistogeten in de Afdeeling Gorontalo Gedaan of Last der Nederlandsch Indische Regering. Frederik Muller.

Saptaningrum, I., Hascaryo, A. T., Chawari, M., Marzuki, I. W., Tihandarko, A., Mamahani, L., Erik, Y., Ramina, B., Andrianto, D. C., \& Ponto, J. (2019). Arsitektur Benteng Maas (Ota Maas) di Kabupaten Gorontalo Utara.

Wall, V. . Van de. (1929). Kort Overzicht van de Nederlandsche Oudheden in Celebes. In Oudheidkundig Verslag 1928. Koninklijk Bataviaasch Genootschap van Kunsten en Wetenschappen (pp. 109-122). Albrecht \& Co.

\section{HASIL DISKUSI}

Tidak Ada Pertanyaan 